\title{
Equal Liberty - Questioning the Right to Freedom of Religion?
}

\author{
Irene Klissenbauer | ORCID: 0000-0003-4482-969X \\ Independent Researcher, Vienna, Austria \\ irene.klissenbauer@orf.at
}

\begin{abstract}
This paper tackles the question of how to handle the phenomenon of "religion" by widely secularized judicial systems by analyzing the "Equal Liberty"-concept from legal scholars Eisgruber and Sager. While they assume that everything worth protecting is already covered by existing anti-discrimination laws, freedom of expression and association, and judge the right to religious freedom as itself discriminatory, this paper considers how this right can be part of an emancipatory human rights approach, which helps us think beyond an antagonistic relationship between religious freedom and other human rights.
\end{abstract}

\section{Keywords}

right to religious freedom and belief - Equal Liberty - anti-discrimination law human rights

\section{Freedom of Religion - a Human Right under Pressure ${ }^{1}$}

Freedom of religion has long been considered one of the first and most important basic rights. ${ }^{2}$ Despite its long history and implementation as a basic human

1 Even though the term "freedom of religion and belief" is to be favored, I use "freedom of religion" here instead to express that the discussion about the equality of religion and belief in this context is still ongoing. For further information see: Bielefeldt, Privileging the ,Homo Religiosus??, pp. 9-24.

2 See Joas, Die Sakralität der Person, p. 48 et seq. 
right, ${ }^{3}$ freedom of religion is being put under increasing pressure worldwide. ${ }^{4}$ One of the practical problems is to be seen in the developments in India, for example, where despite its long history of religious tolerance, religious minorities today face mounting repression as local political leaders very often do not speak out against increasing incidents of violence by Hindu nationalist groups but publicly promote Hindu supremacy and ultra-nationalism. ${ }^{5}$ Another example would be the highly problematic situation in countries such as Saudi Arabia and Afghanistan where religious and secular law are not separated. As a result, these states do not guarantee religious freedom, but have introduced different forms of "religious tolerance" ${ }^{\prime \prime}$ instead, which, consequently, means non-equality under the law. Like many of those states, and besides Saudi Arabia and Afghanistan, Iran prohibits converting from Islam to any other religion and regards atheism as being on par with terrorism. ${ }^{7}$ Problematic tendencies are also noticeable in Russia with its blasphemy law and measures directed against religious minorities, such as Jehovah's Witnesses, by criminalizing their activities. ${ }^{8}$

Apart from these state violations of the right to religious freedom, freedom of religion faces challenges on a more conceptual level too, such as tendencies of "systematic obscuration" (systematische Vernebelung). ${ }^{9}$ One example for this would be when religion is interpreted as a symbol for collective identity, as if religion was only one of several ethnic characteristics or as if religion was seen as equal to race. If we take religious freedom into account, problematic issues arise as, according to this approach, conversion - which is one essential part of religious freedom - is impossible, as one cannot change one's ethnicity. Another example would be the misuse and re-interpretation of religious

3 See Czermak/Hilgendorf, Religions- und Weltanschauungsfreiheit, esp. pp. 1-13; Potz, Zur Geschichte der Religionsfreiheit, pp. 51-66; Brieskorn, Der Kampf um die Religionsfreiheit in der Geschichte, pp. 15-28.

4 See United States Commission on International Religious Freedom, 2018 Annual Report; Pew Research Center, Restrictions on Religion among the 25 most populous countries 2007-2015.

5 See U.S. Department of State, India 2017 International Religious Freedom Report; Kronstadt, India: Religious Freedom Issues.

6 See Klissenbauer, Das Ringen um Religionsfreiheit, p. 247.

7 See Linkvist, Religious Freedom and the Universal Declaration of Human Rights, esp. pp. 98-104; For Saudi Arabia see Freedom House, Freedom in the World 2018; United States Commission on International Religious Freedom, 2018 Annual Report; For Afghanistan see: United Nations, Assistance Mission in Afghanistan.

8 See United States Commission on International Religious Freedom, 2018 Annual Report, pp. 72-8o; Slupina, Religious Freedom and Jehovah's Witnesses in Putin's Russia, pp. 183-222.

9 See Bielefeldt, Religionsfreiheit als Menschenrecht. 
freedom as a right against specific emancipation movements and its use to oppose freedom of opinion and speech. ${ }^{10}$

This problematic situation becomes in turn aggravated today since we are seeing different signs of decreasing support for religious freedom in liberal countries as well, such as the "increasing erosion of conscience protection of religious individuals and institutions",11 especially when it comes to conflicts between religious freedom and other human rights or claims based on nondiscrimination norms. ${ }^{12}$

These developments, as well as open hostility towards religious people as another sign, ${ }^{13}$ make it obvious that the status of religious freedom is not as secure as many might suppose and that there are still many questions to be answered.

One of them would be whether the human right to freedom of thought, conscience, and religion in its current form is still (or has ever been) the best way to guarantee freedom from religious persecution and intolerance. In the United States especially, this question - as well as the free exercise clause that guarantees religious freedom as such ${ }^{14}$ - is still highly discussed..$^{15}$ Along with other scholars such as Ronald Dworkin ${ }^{16}$ or James W. Nickel, ${ }^{17}$ Christopher L. Eisgruber and Lawrence G. Sager point out that the right to religious freedom - as implemented today - is discriminating in itself as it "imposes a test of religious orthodoxy as a condition of constitutional entitlement."18 Following up on this, Eisgruber and Sager develop a new concept to overcome the supposed problems that the right to religious freedom produces. Given the current situation of religious freedom and the aim of the mentioned concept to ensure that freedom of religion or belief of each individual can be guaranteed in the long term, such an approach is worth looking at more closely. As Eisgruber and Sager focus on the implementation of religious freedom in the

10 See Clarkson, When Exemption is the Rule; Mokhtar, The Christian Nation Debate and the U.S. Supreme Court.

11 Glendon, Is Religious Freedom an 'Orphaned' Right?, pp. 1-8, here p. 3.

12 See e.g. Jenichen, Frauenrechte und Religionsfreiheit in Europa, pp. 139-146; Bielefeldt/ Ghanea/Wiener, Freedom of Religion or Belief, pp. 363-389.

13 See Glendon, Is Religious Freedom an 'Orphaned' Right?, pp. 1-8, here p. 3.

14 See Greenawalt, Religion and the Constitution.

15 See McConnell, The Problem of Singling out Religion; Nickel, Who needs freedom of religion?; Hertzke, Religious Freedom in the World Today, pp. 108-133; Durham, Jr., Religious Freedom in a Worldwide Setting, pp. 359-389; Glendon, Is Religious Freedom an 'Orphaned' Right?, pp. 1-8, here p. 3; Samuelson, Why Freedom of Worship is not Enough?

16 See Dworkin, Religion without God.

17 See Nickel, Who needs freedom of religion?, pp. 941-964.

18 Eisgruber/Sager, Religious Freedom and the Constitution, p. 11. 
United States of America, some particularities to that country will be highlighted in the following.

Even though it was evident from the beginning of the international human rights discourse in the 1940s that "the right to religious freedom would constitute one of its main principles", 19 there was no consensus on "precisely what was meant by the term or how it should be framed in a future international instrument."20 Despite this shortcoming, the outcome of these discussions - articulated in article 18 of the Universal Declaration of Human Rights (UDHR) - were later characterized as "one of the most influential statements of the religious rights of mankind yet devised":21

Everyone has the right to freedom of thought, conscience and religion; this right includes freedom to change his religion or belief, and freedom, either alone or in community with others and in public or private, to manifest his religion or belief in teaching, practice, worship and observance. $^{22}$

With reference to the development of religious freedom in the United States, Ericksen emphasizes the great importance of religious freedom, not only as a legal concept, but also in the minds of Americans, and "a very widespread tolerance for disparate religious movements and beliefs". ${ }^{23}$ Even though religious freedom - as understood in the UDHR - was not the intention of early American colonists, one incentive to leave Europe was their seeking the freedom to create religious communities and worship in line with their own belief. ${ }^{24}$ That may be one reason why religious freedom was then (and still is) considered by many Americans as deeply interwoven with the history of the United States and its democracy.

Nevertheless, in the United States, the right to religious freedom was also only gradually understood as a right guaranteeing freedom of thought, conscience, and religion for all human beings, not just for those who believe in

\footnotetext{
19 Lindkvist, Religious Freedom and the Universal Declaration of Human Rights, p. 1.

20 Lindkvist, Religious Freedom and the Universal Declaration of Human Rights, p. 3.

21 Evans, Religious Liberty and International Law in Europe, p. 192.

22 United Nations, Universal Declaration of Human Rights.

23 Ericksen, The Understanding of Religious Freedom in the United States, p. 147.

24 See Ericksen, The Understanding of Religious Freedom in the United States, p. 147.
} 
Jesus Christ. ${ }^{25}$ With the adoption of the First Amendment to the United States Constitution in 1791 and its Establishment Clause (prohibiting a state church) in accordance with the free exercise clause, the modern understanding of religious freedom in the US, which in the long term also significantly influenced the development of the right to freedom of religion as a human right, was developed. In the beginning, the reach of federal governments was the only element which was restricted and then following the reconstruction amendments adopted after the American civil war, some of the protections of the Bill of Rights such as the Establishment Clause and the Free Exercise Clause, were extended to state governments in the 1920 s. ${ }^{26}$ While a detailed description of the history of religious freedom in the United States is not feasible in this paper, ${ }^{27}$ it needs to be emphasized that one essential part of this understanding of religious freedom was the conviction of having an ideal relationship between church and state, summarized with the term of the so-called wall of separation. Originally coined by Roger Williams, ${ }^{28}$ the metaphor became famous under Thomas Jefferson, and part of the American legal framework after its quotation by the Supreme Court in $1947 .{ }^{29}$ Handling the legal case Everson v. Board of Education of the Township of Ewing, Justice Hugo Black emphasized that: "The First Amendment has erected a wall between church and state. That wall must be kept high and impregnable. We could not approve the slightest breach." ${ }^{30}$ Even though the emphasis on the wall of separation by the Supreme Court was seen by many as typical for the Enlightenment ideals and the history of religious freedom in the United States, its meaning was hotly debated later on. One reason was that in practice, accommodation had always been in place, ${ }^{31}$ so that it was alleged that the emphasis on separation was rhetorical only.

25 The Maryland "Toleration Act" of 1649 gave religious freedom only to Christian denominations, implying no toleration toward others. See Ericksen, The Understanding of Religious Freedom in the United States, p. $15^{2}$ et seq.

26 See Ericksen, The Understanding of Religious Freedom in the United States, p. 152 et seq.

27 For more information see for example Winandy, Der Kampf um Religionsfreiheit, pp. 18720o; Kidd, Jefferson, Madison, Henry, pp. 33-52; Ericksen, The Understanding of Religious Freedom in the United States, pp. 147-165.

28 See Miller, Roger Williams.

29 See Ericksen, The Understanding of Religious Freedom in the United States, p. 152.

30330 U.S. 1, Everson v. Board of Education of the Township of Ewing (No. 52), Argued: November 20, 1946, Decided: February 10, 1947, 133 N.J.L. 350, 44 A.2d 333, affirmed. Especially Justice Hugo Black, having ties to the Ku Klux Klan, got criticized later on as being anti-Catholic, see Hamburger, Separation of Church and State, esp. p. 461 et seq.

31 See for example the Everson case in 1947, cited in footnote 30. 
This discussion is still ongoing. Separationists (those who argue for a very strict separation) emphasize the wall's aim to guarantee that churches (or more general religions) do not influence political activities (or do not play any part in political activities whatsoever). ${ }^{32}$ Accommodationists are rejecting this approach, and "argue in favor of accommodating certain benefits for religion in practice, ${ }^{33}$ stressing that the wall of separation is to be understood as a protective wall for the churches (or more general religions) against the state. ${ }^{34}$

Eisgruber's and Sager's concept starts at this very point, dismissing the underlying common debate on the issue of whether religion and state are permitted to affect each other as misleading. ${ }^{35}$ According to Eisgruber and Sager, the discussion about the wall of separation is dispensable since the notion of the separation in this context is "implausible in the extreme. [...] Church and state are not separate in the United States, and they cannot possibly be separate." ${ }^{36}$ As a consequence, the crucial question is rather how religion and state affect each other and how they should be permitted to do so. ${ }^{37}$ Such a focus-shift would be even more necessary as the misleading debate on the separation of church and state fosters other misinterpretations in this context too, like the reading of the "Religious Freedom Restoration Act" (RFRA) ${ }^{38}$ as "religious exemption" only. ${ }^{39}$ To exemplify this mentioned problem, Eisgruber and Sager refer to a fictitious example of two women named Ms. Campbell, who want to open soup kitchens to feed the homeless. Both of them are confronted with zoning restrictions banning their project. While the first Ms. Campbell, having been religiously motivated, "has a constitutional right to ignore the zoning ordinance", 40 the second Ms. Campbell, motivated by her "abhorrence

32 See Winandy, Der Kampf um Religionsfreiheit, pp. 187-200, p. 193. This disagreement about the church-state-relationship goes back to the era of the Founding Fathers themselves. See Muñoz, The Founding Fathers' Competing Visions, pp. 53-68.

Ericksen, The Understanding of Religious Freedom in the United States, here p. 154.

34 See for example Winandy, Der Kampf um Religionsfreiheit, here p. 194.

35 See Eisgruber/Sager, Religious Freedom and the Constitution, p. 7.

36 Eisgruber/Sager, Religious Freedom and the Constitution, p. 6.

37 See Eisgruber/Sager, Religious Freedom and the Constitution, p. 7.

${ }_{3} 8$ While the free exercise clause already guaranteed religious freedom, concrete technical standards on how to deal with conflicting individual and state interests were missing until 1963 when the Supreme Court established the so-called "compelling state interest test", and after conflicts in interpretation of this test the Religious Freedom Restoration Act (RFRA) was adopted in 1993. See Martin/Finke, Defining and Redefining Religious Freedom, esp. pp. 98-10o.

39 Eisgruber/Sager, Religious Freedom and the Constitution, pp. 83-85.

40 Eisgruber/Sager, Religious Freedom and the Constitution, pp. 83-85. 
of human suffering", 41 "must obey the ordinance", ${ }^{42}$ as there are no exemption clauses based on non-religious convictions. According to Eisgruber and Sager, a consequence is that the free exercise clause is interpreted to "give religiously motivated persons a presumptive right to disobey the law".43 The following variety of possible conflicts is, as Eisgruber and Sager stress, "as vast as the variety of religious obligations in America - which is to say, about as vast as one can imagine". 4

Despite "the good reason to celebrate the success of America's great constitutional experiment with religious freedom" so far, ${ }^{45}$ it becomes evident that Americans find themselves in an increasingly angry confrontation over the interplay of religion, politics, and law, because of those demands for "religious exemption". ${ }^{46}$ What is even more alarming is that one can sense the decrease in the willingness to find solutions to these conflicts. As previous discussions furthermore ignore the shifting of religious boundaries and alliances and the changing conflicts that involve religious freedom, Eisgruber and Sager stress that a totally new approach is needed:

Our foremost goal [...] is to return to the project of religious freedom, the project of finding fair terms of cooperation for a religiously diverse people. [...] Like the framers of the Constitution, we are concerned with both liberty and equality, and we call the approach that results from these joined concerns 'Equal Liberty'. ${ }^{47}$

\section{$3 \quad$ Equal Liberty - a Better Way of Guaranteeing Religious Freedom?}

What lies beneath the contemporary problematic situation of religious freedom in the United States, as previously mentioned, is the dominant approach that centers on the metaphor of "the separation of church and state". According to Eisgruber and Sager, this discourse "extrapolates principles that alternately direct that religion be treated much better or much worse than other important human projects." ${ }^{48}$ Eisgruber and Sager, in contrast, insist that there is no reason

\footnotetext{
41 Eisgruber/Sager, Religious Freedom and the Constitution, pp. 83-85.

42 Eisgruber/Sager, Religious Freedom and the Constitution, pp. 83-85.

43 Eisgruber/Sager, Religious Freedom and the Constitution, p. 11.

44 Eisgruber/Sager, Religious Freedom and the Constitution, p. 12.

45 Eisgruber/Sager, Religious Freedom and the Constitution, p. 3.

46 Eisgruber/Sager, Religious Freedom and the Constitution, p. 3.

47 Eisgruber/Sager, Religious Freedom and the Constitution, p. 4.

48 Eisgruber/Sager, Religious Freedom and the Constitution, p. 5.
} 
to confer special constitutional privileges or to impose special constitutional disabilities upon religion as it is not "a category of human experience that demands special benefits and/or necessitates special restrictions", ${ }^{49}$ but rather "one important source of commitment and fulfillment among many". ${ }^{50}$ As a consequence, governments need to take the fact seriously that people have "diverse commitments regarding religion (including, in some cases, a commitment to reject religion) and [...] [that] those commitments are important components of identity and well-being."51 Following these considerations, it is not the state's place to ask what religion is or what the value of convictions is like. Its only duty is to guarantee equality and distributional fairness ${ }^{52}$ and to be aware of the fact that religious as well as non-religious commitments can be compelling in a way that people would rather die than compromise them. ${ }^{53}$ Therefore it is necessary to shift the focus towards how to treat individuals (not how to behave toward religion) and realize that the question "whether government support for religion being a good thing" 54 or about public religion being good for society proves to be "profoundly speculative and intensely divisive".55

Taking these considerations as a starting-point, Eisgruber and Sager argue as the Accommodationists do, thus in favor of accommodation, stressing that their approach will not only call for exemptions, but also helps to explain why these accommodations provide such attractive opportunities for all citizens. ${ }^{56}$ This is clearly exemplified by the attention given to dress code cases as well as medical care or prison diet cases in practice.

Focusing on practical cases, Eisgruber and Sager criticize that the current system, summarized as the "balancing approach", favors religious accommodation at the expense of other public interests, even though the Constitution does not impose any such preference. ${ }^{57}$ In contrast to this approach, Equal Liberty "calls on government to exempt religious observers [sic!] from burdens that are not shared fairly with others $[. .$.$] and insists that religious persons,$ organizations, and practices must share fairly in the burdens and limitations that go along with membership in organized society." ${ }^{58}$ They emphasize in

49 Eisgruber/Sager, Religious Freedom and the Constitution, p. 6.

$5^{\circ}$ Eisgruber/Sager, Religious Freedom and the Constitution, p. 62.

$5^{1}$ Eisgruber/Sager, Religious Freedom and the Constitution, p. 53.

$5^{2}$ See Eisgruber/Sager, Religious Freedom and the Constitution, p. 19 et seq.

53 See Eisgruber/Sager, Religious Freedom and the Constitution, p. 104.

54 Eisgruber/Sager, Religious Freedom and the Constitution, p. 19.

55 Eisgruber/Sager, Religious Freedom and the Constitution, p. 18.

$5^{6}$ See Eisgruber/Sager, Religious Freedom and the Constitution, p. 97.

57 See Eisgruber/Sager, Religious Freedom and the Constitution, p. 86.

$5^{8}$ Eisgruber/Sager, Religious Freedom and the Constitution, p. 87. 
this context that laws are not unjust "simply because they impose a minor burden on some and a much greater burden on others", 59 as this is what they do all the time. Rather, the justice of such accommodations is to be seen in whether "the state shows the same concern for the fundamental needs of all its citizens." ${ }^{\circ 0}$ Therefore it is inevitable to find "principled consistency across cases rather than conformity to some idealized, theoretically specified regulatory equilibrium". ${ }^{61}$ To exemplify these considerations, Eisgruber and Sager refer to different legal cases, for instance the police case Faruq Abdul-Aziz and Shakoor Mustafa versus City of Newark; Newark Police Department: ${ }^{62}$ Faruq Abdul-Aziz and Shakoor Mustafa, members of the Newark, New Jersey Police Department, were prohibited to grow a beard out of religious reasons, as only exceptions from the departmental grooming regulation based on medical reasons (folliculitis) were allowed. ${ }^{63}$ Such a differentiation, as not only the U.S. Court of Appeals for the Third Circuit, ${ }^{64}$ but also Eisgruber and Sager criticize $^{65}$ is not justifiable as citizens were not treated equally, even though secular and religious needs are plainly analogous here:

So, for example, skin irritation may be a trivial burden by comparison to the wrath of Allah, but if a police department prohibited all officers from wearing beards, the regulation would have much the same impact on folliculitis sufferers and Muslims: neither group could serve in the police force. ${ }^{66}$

In order to avoid such inadmissible differentiation, the Equal Liberty approach - understood as an antidiscrimination and liberty-based theory ${ }^{67}$ insists "on a robust set of constitutional rights available to all persons and groups, without any reference to their religious, nonreligious, or antireligious commitments":68

\footnotetext{
59 Eisgruber/Sager, Religious Freedom and the Constitution, p. 88.

6o Eisgruber/Sager, Religious Freedom and the Constitution, p. 89.

61 Eisgruber/Sager, Religious Freedom and the Constitution, p. 90.

62 See United States Court of Appeals, Third Circuit: Fraternal Order of Police Newark Lodge No. 12.

63 See Gregory, Encountering religion in the workplace, pp. 109-111.

64 See United States Court of Appeals, Third Circuit: Fraternal Order of Police Newark Lodge No. 12.

65 See Eisgruber/Sager, Religious Freedom and the Constitution, p. 91.

66 Eisgruber/Sager, Religious Freedom and the Constitution, p. 104.

67 See Eisgruber/Sager, Religious Freedom and the Constitution, p. 94.

68 Eisgruber/Sager, Religious Freedom and the Constitution, p. 94.
} 
Equal Liberty's antidiscrimination principle requires that the state show equal regard for the religious and the non-religious needs of citizens when it distributes these burdens - by which we mean the burdens of civil law, the only burdens that the state has any power to impose. ${ }^{69}$

As a consequence, Equal Liberty recommends an equality principle that, by comparing religious and non-religious interests, finds analogies that help to develop fair accommodations. Eisgruber and Sager emphasize that all persons, especially those belonging to minority groups, would benefit from such an approach as it "avoids the conceptual quandaries that plague the separation model and the balancing approach, and it provides courts with a sound rationale for upholding free exercise rights". ${ }^{70}$ Religious freedom is therefore to be understood as:

the right to participate in the constitutional project on fair terms, so that one is neither privileged nor disfavored on the basis of the religious (or non-religious) character of one's commitments. Participating on fair terms entails, among other things, having one's religious needs accommodated on the same terms as comparably serious religious and nonreligious needs..$^{71}$

While Eisgruber and Sager are optimistic about the state's ability to find such analogies, Equal Liberty does not depend on the possibility of close comparison of religious and non-religious interests, but on the general willingness and ability to see interests as comparable in principle. They recall the concern of how to deal with disparagement and the so called "tyranny of the thin-skinned",72 that proves to be a fundamental challenge in the context of freedom of religion. These questions arise, inter alia, in the context of religious symbols and events or displays in the public sphere, not least because of the challenge to understand its social meaning that has always been contextual and ambiguous, ${ }^{73}$ but becomes even more controversial in a pluralized society.

However, also in this context, Eisgruber and Sager stress that an emphasis on the state's specific competence and responsibility, that is not to speculate on whether public religion is good for society, but to guarantee equality of

69 Eisgruber/Sager, Religious Freedom and the Constitution, p. 104.

70 Eisgruber/Sager, Religious Freedom and the Constitution, p. 93.

71 Eisgruber/Sager, Religious Freedom and the Constitution, p. 108.

72 Eisgruber/Sager, Religious Freedom and the Constitution, p. 135.

73 See Eisgruber/Sager, Religious Freedom and the Constitution, p. 127. 
its citizens, would help to resolve such conflicts. Exactly through this shift of focus, states would also be able to bear witness to religious contributions to the state's history, without automatically arousing suspicion of discriminating against members of other religious or non-religious beliefs. ${ }^{74}$ Therefore it is absolutely necessary to differentiate between dissimilar contexts, for example public and private spaces, schools and courtrooms, and therefore focus on each accommodation-case in detail. Equal Liberty makes that possible and is therefore to be understood as a starting point for discussing "the concrete implementation of equal regard in constitutional law".75

\section{Conclusion}

Considering what we know about the history of society and living together in harmony, apart from all of the cultural and religious differences, it seems to be obvious that we are only at the beginning of trying to understand what diversity and plurality demand from society and the individual. The decreasing support for religious freedom stems directly from the challenges of finding solutions within these conflicts. As it is absolutely clear that vital changes and developments must take place in relation to maintain the possibility of living together in diversity, the value of Equal Liberty's aim to find "fair rules of cooperation among a religiously diverse people"76 cannot be overestimated. The analysis of current implementation forms of religious freedom is therefore essential and central to such work. This is especially true for the specific understanding of religious freedom in the United States as it does not only affect its implementation in the United States, but also discussions worldwide. The reason therefore is not only the political position of the United States, but also the fact that the leading and (despite the much smaller World Watch List, produced by the NGO Open Doors) only index, produced by the Pew Research Center (PRC) that measures restriction on religious freedom worldwide, follows this specific American understanding of religious freedom and the idea of the wall of separation as ideal. As a result of this one-sided focus, other religion-state-models, like those that have accomplished the separation of religion and state, but at the same time do in fact have religious references in the public sphere, receive no consideration in this Index.

74 See Eisgruber/Sager, Religious Freedom and the Constitution, p. 138.

75 Eisgruber/Sager, Religious Freedom and the Constitution, p. 284.

76 Eisgruber/Sager, Religious Freedom and the Constitution, p. 135. 
Eisgruber's and Sager's approach could be a good starting point for the highly needed discussion on how to ensure that freedom of religion or belief of each individual can be guaranteed in the long term and how to develop new Indices to measure restriction. Therefore, it would be necessary to focus not only on religious freedom in the United States but on the global situation. Therefore, it is regrettable that Equal Liberty does neither compare the advantages and disadvantages of different forms of religion-state-models nor consider existing approaches such as the extension of freedom of religion to freedom of religion and belief. One example worth looking at more closely would have been General Comment no. 22 on article 18, that, as early as 1993, emphasized that recognition of conscientious objections should not differentiate between various kinds of belief. Like Eisgruber and Sager, General Comment no. 22 highlights the necessity of a broad conceptualization of freedom of religion and belief in unambiguous terms:

1. The right to freedom of thought, conscience and religion (which includes the freedom to hold beliefs) in article 18.1 is far-reaching and profound; it encompasses freedom of thought on all matters, personal conviction and the commitment to religion or belief, whether manifested individually or in community with others. The Committee draws the attention of States parties to the fact that the freedom of thought and the freedom of conscience are protected equally with the freedom of religion and belief. The fundamental character of these freedoms is also reflected in the fact that this provision cannot be derogated from, even in time of public emergency, as stated in article 4.2 of the Covenant.

2. Article 18 protects theistic, non-theistic and atheistic beliefs, as well as the right not to profess any religion or belief. The terms "belief" and "religion" are to be broadly construed. Article 18 is not limited in its application to traditional religions or to religions and beliefs with institutional characteristics or practices analogous to those of traditional religions. The Committee therefore views with concern any tendency to discriminate against any religion or belief for any reason, including the fact that they are newly established, or represent religious minorities that may be the subject of hostility on the part of a predominant religious community. ${ }^{77}$ The consideration of this discussion would not necessarily have changed the concept of Eisgruber and Sager, as the extension of freedom of religion to freedom of religion and belief alone does not answer how to deal with the various confrontations over the interplay of religion, politics and law. But it would 
have emphasized the importance of being aware that religious as well as nonreligious commitments can be compelling in a way that people would rather die than compromise them. ${ }^{78}$ Any attempt to strengthen religious freedom must therefore focus on the human particularities of having conscience and an openness towards transcendent experience. ${ }^{79}$ So instead of concentrating on ways to find analogies between all existing human interests - be it medical, religious, or economic, amongst others - Eisgruber's and Sager's aim to defuse the current heated religious-political discourse would be better served by focusing on a discussion about the comparability of philosophical and religious beliefs.

Such an analogy between deep religious and non-religious convictions would also clarify that having such values and principles is an integral part of human life, instead of linking them to medical issues that shift convictions toward the realm of disease and/or difficulties that need to be overcome. This seems to be even more important in a global context where non-religious convictions are disregarded frequently and as a result, non-religious persons are coming under pressure.

Even though the consideration of the case-law by the UN Human Rights Committee since the 199os could have slightly changed Eisgruber's and Sager's focus, far more attention should be given to the relationship of individual and collective freedom of religion. Despite the fact that the question on how to deal with those dimensions of religious freedom is to be seen as one of the major challenges of the implementation of religious freedom in many countries worldwide, further reflections on the relationship of these dimensions are still a desideratum. ${ }^{80}$ This may be due to the fact that most approaches do not pay sufficient attention to the global situation.

However, the fact that Eisgruber and Sager focus on the questions of religious freedom in the US context only becomes even more problematic as such an approach fails to consider the fact that an individual constitutional change (that is one at the national level only) of the fundamental human right to religious freedom would also have a colossal effect on a global level. The visible lack of awareness of the consequences such an approach could have is - at best - a sign for the already mentioned misjudgment that the status of religious freedom is to be seen as secure in any way, which, however, is falsified by any look at political realities. In contrast, the acknowledgement in policy

\footnotetext{
78 See Eisgruber/Sager, Religious Freedom and the Constitution, p. 104.

79 See Wunn, Barbaren, Geister, Gotteskrieger; In this context also Illing/Evers, Neurologie und Kognitionswissenschaft.

8o See for example Kirchschläger, Liberaler Rechtsstaat, pp. 305-326.
} 
shows that religious freedom as a human right is gravely violated and at risk in many countries, especially when it comes to the freedom to change one's religion or belief. Therefore, any attempt to dispel religious freedom, arguing that everything worth protecting is already covered by existing anti-discrimination laws, freedom of expression and association, ${ }^{81}$ ignores this fact and the possible legal effects for concerned persons. Against this global background, the question that begs to be answered is what consequences the dispersal of religious freedom in the United States would have in other countries, such as Saudi Arabia, to name but one.

Instead of dismissing religious freedom in its current form, Equal Liberty with its important emphasis on the individual person rather than on religions, should therefore stress that religious freedom is not only an individual right, but also a right of freedom. Such an emphasis would not only highlight the importance of freedom and equality, that Eisgruber and Sager focus on, but also clarify that anti-apostasy provisions are

in obvious breach of the freedom of religion or belief, which unequivocally corroborates people's freedom to 'change' their religion or belief $[\ldots]$ or any person's freedom to 'have or to adopt a religion or belief of his choice.'82

It is also against this background that the rejection of religion, being a "constitutional anomaly, a category of human experience that demands special benefits", ${ }^{83}$ does not seem to be useful to guarantee religious freedom for religious and non-religious people alike. Such an approach could otherwise be used to reject questions of conscience that do not follow the majority's convictions.

The decisive point for the successive realization of religious freedom worldwide nowadays is not only if states implement religious freedom as a human right and guarantee freedom from religious persecution. It will also be crucial that we are able to develop an approach that helps us think beyond an antagonistic relationship between religious freedom and other human rights. ${ }^{84}$ Eisgruber's and Sager's concept can provide a starting point to support

\footnotetext{
81 See Eisgruber/Sager, Religious Freedom and the Constitution.

82 UN General Assembly, Interim report of the Special Rapporteur A/71/269, para. 43 .

83 Eisgruber/Sager, Religious Freedom and the Constitution, p. 6.

84 In this context see for example: Jenichen, Frauenrechte und Religionsfreiheit in Europa, pp. 139-146; Trigg, Equality, Freedom \& Religion; Amor, Study on Freedom of Religion or Belief and the Status of Women; Klissenbauer, Universale Normen angesichts gesellschaftlicher Pluralität.
} 
religious freedom as part of an emancipatory human rights approach, ${ }^{85}$ not so much by the developed consequences, but by strengthening their foundations that focus on the freedom of the individual and the states' aim to guarantee equality and distributional fairness. Considering the increasing (or increasingly visible) plurality of society, the secular state therefore is to be understood and constructed as open-minded towards "religious and non-religious beliefs", that is as a state that starting from the freedom of religion and belief enables all its citizens to shape its ethical and cultural fundaments in the field of human rights.

\section{Biography}

Dr. Irene Klissenbauer is a researcher at the Institute for Systematic Theology and Ethics at the University of Vienna (Faculty of Catholic Theology). She conducts research on the right to religious freedom and belief, the relationship between religion and state, gender justice, women's rights in Christianity and Islam, and religious-feminist online activism.

\section{Bibliography}

Amor, Abdelfattah: Study on Freedom of Religion or Belief and the Status of Women in the Light of Religion and Traditions, https://documents-dds-ny.un.org/doc/UNDOC/ GEN/Go8/110/35/PDF/Go811035.pdf?OpenElement (date of last access: 11.01.2021).

Ben Barka, Mokhtar: The Christian Nation Debate and the U.S. Supreme Court, in: European Journal of American Studies Special Issue: Oslo Conference 6 (2/2011), http://journals.openedition.org/ejas/8882 (date of last access: 11.01.2021).

Bielefeldt, Heiner: Religionsfreiheit als heilsame Provokation. Dankesrede anlässlich der Verleihung des Alfons Auer - Ethik - Preises, in: Theologische Quartalschrift 198 (3/2018), pp. 146-162.

Bielefeldt, Heiner: Religionsfreiheit als Menschenrecht, Vortrag im Rahmen der Jahrestagung des Internationalen Instituts für missionswissenschaftliche Forschungen e.V.: Religionsfreiheit - gefährdetes Menschenrecht?, 07.12.2018-08.12.2018, Erbacher Hof: Akademie des Bistums Mainz, 07.12.2018.

Bielefeldt, Heiner/Ghanea, Nazila/Wiener, Michael: Freedom of Religion or Belief. An International Law Commentary. Oxford: Oxford University Press 2016.

85 See Bielefeldt, Religionsfreiheit als heilsame Provokation, pp. 146-162. 
Bielefeldt, Heiner: Privileging the ,Homo Religiosus? Towards a Clear Conceptualization of Freedom of Religion and Belief, in: Malcom D. Evans/Peter Petkoff/Julian Rivers (eds.): The Changing Nature of Religious Rights Under International Law. Oxford: Oxford University Press 2015, pp. 9-24.

Brieskorn, Norbert: Der Kampf um die Religionsfreiheit in der Geschichte, in: Heiner Bielefeldt/Volkmar Deile/Brigitte Hamm/Franz-Josef Hutter/Sabine Kurtenbach/ Hannes Tretter-Böhlau (eds.): Religionsfreiheit. Jahrbuch Menschenrechte 2009. Wien/Köln/Weimar: DeGruyter 2008, pp. 15-28.

Clarkson, Frederick: When Exemption is the Rule. The Religious Freedom Strategy of the Christian Right, Political Research Associates 2016, https://www.politicalresearch .org/when-exemption-is-the-rule-the-religious-freedom-strategy-of-the-christian -right/ (date of last access: 11.01.2021).

Czermak, Gerhard/Hilgendorf, Eric: Religions- und Weltanschauungsfreiheit. Eine Einführung, Vol. 2. Schweiz: Springer-Lehrbuch/eBook 2018.

Durham, Cole W. Jr.: Religious Freedom in a Worldwide Setting: Comparative Reflections, in: Mary Ann Glendon/Hans F. Zacher (eds.): UniversalRights in a World of DiversityThe Case of Religious Freedom, Seventeenth Plenary Session, 29.04.2011-03.05.2011, Vatican City 2012, pp. 359-389, http://www.pass.va/content/scienzesociali/en/pub lications/acta/religiousfreedom.html (date of last access: 11.01.2021).

Dworkin, Ronald: Religion without God. Cambridge, MA: Harvard University Press 2013. Eisgruber, Christopher L./Sager, Lawrence G.: Religious Freedom and the Constitution. Cambridge, MA: Harvard University Press 2007.

Ericksen, Robert P.: The Understanding of Religious Freedom in the United States, in: Religion-Staat-Gesellschaft.Zeitschrift für GlaubensformenundWeltanschauungen/ Journal for the Study of Beliefs and Worldviews 14 (1/2013), pp. 147-165.

Evans, Malcom D.: Religious Liberty and International Law in Europe. Cambridge, MA: Cambridge University Press 1997.

Freedom House: Freedom House Report: Freedom in the World 2018, in: Saudi Arabia Profile, https://freedomhouse.org/report/freedom-world/2018/saudi-arabia (date of last access: 11.01.2021).

Glendon, Mary Ann: Is Religious Freedom an 'Orphaned' Right?, in: Malcom D. Evans/ Peter Petkoff/Julian Rivers (eds.): The Changing Nature of Religious Rights Under International Law. Oxford: Oxford University Press 2015, pp. 1-8.

Greenawalt, Kent: Religion and the Constitution. Vol. 1: Free Exercise and Fairness. Princeton; Oxford: Princeton University Press 2006.

Gregory, Raymond F.: Encountering religion in the workplace: the legal rights and responsibilities of workers and employers. Ithaca; London: ILR Press 2010.

Hamburger, Philip: Separation of Church and State. Cambridge, MA: Harvard University Press 2002. 
Hertzke, Allen D.: Religious Freedom in the World Today: Paradox and Promise, in: Mary Ann Glendon/Hans F. Zacher (eds.): Universal Rights in a World of Diversity - The Case of Religious Freedom, Seventeenth Plenary Session, 29.04.-03.05.2011, Vatican City 2012, pp. 108-133, http://www.pass.va/content/scienzesociali/en/publications/ acta/religiousfreedom.html (date of last access: 11.01.2021).

Hoffmann, Anja Nicole: Measuring freedom of religion: an analysis of religious freedom. Vienna: University of Vienna, MA-Thesis 2017.

Illing, Robert-Benjamin/Evers, Dirk: Neurologie und Kognitionswissenschaft: Entsteht Religion im Gehirn?, Streitgespräche über Gott und die Welt, Veranstaltung zum 100-jährigen Bestehen der Evangelisch-Theologischen Fakultät in Zusammenarbeit mit dem Exzellenzcluster „Religion und Politik“, 20.05.2014.

Jenichen, Anne: Frauenrechte und Religionsfreiheit in Europa - ein Plädoyer für Versöhnung statt Hierarchisierung, in: Karrieren und Lebenswelten - Irritationen, Dynamiken, Strategien 6 (3/2014), pp. 139-146.

Joas, Hans: Die Sakralität der Person. Eine neue Genealogie der Menschenrechte, Vol. 3 , Berlin: Surkamp 2011.

Kidd, Thomas S.: Jefferson, Madison, Henry, and the Context for Religious Liberty in Revolutionary America, in: Allen D. Hertzke (ed.): Constitutional Roots and Contemporary Challenges: Religious Freedom in America. Oklahoma: Norman 2015, pp. $33^{-52 .}$

Kirchschläger, Peter G.: Liberaler Rechtsstaat - Menschenrechte - Religions-, und Weltanschauungsgemeinschaften, in: Irene Klissenbauer/Franz Gassner/Petra Steinmair-Pösel/Peter G. Kirchschläger (eds.): Ethik - Religion - Menschenrechte. Gerechtigkeit und Dialog als bleibende Herausforderungen. Vienna:Vienna University Press 2020, pp. 305-326.

Klissenbauer, Irene: Universale Normen angesichts gesellschaftlicher Pluralität. Die Bedeutung der Genderforschung für Menschenrechte und Theologie, in: Marianne Heimbach-Steins/Judith Könemann/Verena Suchhart-Kroll (eds.): Gender (Studies) in der Theologie - Begründungen und Perspektiven, Münsterische Beiträge zur Theologie 4, Münster: Aschendorff (forthcoming).

Klissenbauer, Irene: Das Ringen um Religionsfreiheit. Die Positionen von John Courtney Murray und Fethullah Gülen im Vergleich. Wien: Lit 2015.

Kronstadt, K. Alan: India: Religious Freedom Issues, Congressional Research Service 2018, https://fas.org/sgp/crs/row/R45303.pdf (date of last access: 11.01.2021).

Law Cornell: Supreme Court Text 330 U.S. 1 , https://www.law.cornell.edu/supremecourt / text/33o/1 (date of last access: 11.01.2021).

Linkvist, Linde: Religious Freedom and the Universal Declaration of Human Rights. New York: Cambridge University Press 2017.

Martin, Robert R./Finke, Roger: Defining and Redefining Religious Freedom. A Quantitative Assessment of Free Exercise Cases in the U.S. State Courts, 1981-2011, in: 
Allen D. Hertzke (ed.): Religious Freedom in America: Constitutional Roots and Contemporary Challenges. Oklahoma: Norman 2015, pp. 91-116.

McConnell, Michael W.: The Problem of Singling out Religion, in: DePaul Law Review 50 (1/200o), https://via.library.depaul.edu/law-review/vol5o/issi/2 (date of last access: 11.01.2021).

Miller, Perry: Roger Williams: His contribution to the American tradition. New York: Atheneum 1974.

Muñoz, Vincent Phillip: The Founding Fathers' Competing Visions for the Proper Separation of Church and State, in: Allen D. Hertzke (ed.): Religious Freedom in America: Constitutional Roots and Contemporary Challenges. Oklahoma: Norman 2015, pp. 53-68.

Nickel, James W.: Who needs freedom of religion?, in: Colorado Law Review 76 (4/2005), pp. 941-964.

Pew Research Center: Restrictions on religion among the 25 most populous countries 2007-2015, April 2017, http://www.pewforum.org/interactives/restrictions-on-reli gion-among-the-25-most-populous-countries-2007-2015/ (date of last access: 11.01.2021).

Potz, Richard: Zur Geschichte der Religionsfreiheit, in: Ernst Fürlinger (ed.): Die Freiheit der Religion. Ein klassisches Menschenrecht in der Kontroverse, Vol. 2, Krems: Tredition 2017, pp. 51-66.

Samuelson, Ashley: Why Freedom of Worship is not Enough?, in: First Things, 22.11.2010, https://www.firstthings.com/web-exclusives/2010/o2/why-ldquofreedom-of-worship rdquo-is-not-enough (date of last access: 11.01.2021).

Slupina, Wolfram: Religious Freedom and Jehovah's Witnesses in Putin's Russia, Georgia, and CIS, in: Religious Freedom. Its Confirmation and Violation during the 2oth and 21st Centuries, Religion - Staat - Gesellschaft. Zeitschrift für Glaubensformen und Weltanschauungen/Journal for the Study of Beliefs and Worldviews 18 (1-2/2017), pp. 183-222.

Trigg, Roger: Equality, Freedom \& Religion. Oxford: Oxford University Press 2013.

United Nations: Universal Declaration of Human Rights. Article 18, http://www.un.org/ en/universal-declaration-human-rights/ (date of last access: 11.01.2021).

United States Commission on International Religious Freedom: 2018 Annual Report, https://www.uscirf.gov/reports-briefs/annual-report/2018-annual-report (date of last access: 11.01.2021).

United States Court of Appeals: Third Circuit: Fraternal Order of Police Newark Lodge No. 12: Faruq Abdul-Aziz; Shakoor Mustafa v. City of Newark; Newark Police Department; Joseph J. Santiago, Newark Police Director; Thomas C. O'Reilly, Newark Chief of Police, Appellants. No. 97-5542, Decided: March 03, 1999, https://caselaw .findlaw.com/us-3rd-circuit/1022700.html (date of last access: 11.01.2021). 
United Nations, United Nations Assistance Mission in Afghanistan: Special Report on Protection of Civilians in Armed Conflict: Attacks against Places of Worship, Religious Leaders and Worshippers, 7.11.2017, https://unama.unmissions.org/protection-of -civilians-reports (date of last access: 11.01.2021).

UN General Assembly: Interim report of the Special Rapporteur, A/71/269.

UN Human Rights Committee (HRC): CCPR General Comment No. 22: Article 18 (Freedom of Thought, Conscience or Religion), 30 July 1993, CCPR/C/21/Rev.1/Add.4, https://www.refworld.org/docid/453883fb22.html (date of last access: 11.01.2021).

U.S. Department of State: India 2017 International Religious Freedom Report, Executive Summary, see https://www.state.gov/documents/organization/281266.pdf (date of last access: 11.01.2021).

Winandy, Julien: Der Kampf um Religionsfreiheit: Roger Williams und Thomas Jefferson, in: Oliver Hidalgo/Christian Polke (eds.): Staat und Religion. Zentrale Positionen zu einer Schlüsselfrage des politischen Denkens, Staat - Souveränität - Nation. Beiträge zur aktuellen Staatsdiskussion. Wiesbaden: Springer vs 2017, pp. 187-200.

Wunn, Ina: Barbaren, Geister, Gotteskrieger. Die Evolution der Religionen. Berlin; Heidelberg: Springer 2018. 